\title{
PENGGUNAAN MODEL PEMBELAJARAN PROBLEM BASED LEARNING BERBANTU MEDIA KONKRIT DALAM UPAYA PENINGKATAN PROSES DAN HASIL BELAJAR MUATAN IPA TEMA7 SUBTEMA 1 KELAS 4
}

\author{
Chinda Hibatul Buda ${ }^{1}$, Nyoto Harjono ${ }^{2}$, Gamaliel Septian Airlanda ${ }^{3}$ \\ PGSD - FKIP - Universitas Kristen Satya Wacana \\ chindah86@gmail.com, har.john59@gmail.com, gama.airlanda@staff.uksw.edu
}

\begin{abstract}
ABSTRAK
Penelitian dilaksanakan guna meningkatkan prosesdan hasil belajar dengan berbantu media konkrit pada muatan IPA yang terdapat pada Tema 7 subtema 1 . Penelitian dilaksanakan pada tanggal 7 Mei-16 Mei 2018 pada siswa kelas 4 SD Negeri Tegalrejo 01 tahun ajaran 2017/2018. Jenis penelitian menggunakan penelitian tindakan kelas. Teknik pengumpulan data menggunakan lembar observasi guru dan siswa serta tes tertulis pilihan ganda. Hasil belajar siswa pada prasiklus berjumlah 11siswa dengan persentase 40,74\%, dantidak tuntas 16 siswa dengan persentase $59,26 \%$. Setelah melakukan perbaikan pada siklus I terjadi peningkatan ketuntasan yaitu 19 siswa tuntas dengan persentase 70,37\% dan 8 siswa tidak tuntas dengan persentase $29,63 \%$, hasil dari perbaikan siklus I belum mencapai indikator pencapaian yakni $80 \%$ ketuntasan, maka di laksanakan perbaikan siklus II. Setelah pelaksanaan siklus II terjadi peningkatanketuntasan yaitu 23 siswatuntas dengan persentase $85,19 \%$ sedangkan siswa yang tidak tuntas berjumlah 4 orang dengan persentase $14,81 \%$. Dengan demikian perbaikan dengan Model Problem Based Learning Berbantu Media konkrit dapat di katakan berhasil karena hasil belajar mencapai tujuan yakni persentase $80 \%$. Sehingga Model Problem Based Learning Berbantu Media konkrit dianjurkan agar siswa lebih aktif dalam kegiatan pembelajaran yang berlangsung.
\end{abstract}

Kata Kunci: Problem Based Learning, Media Konkrit, Proses dan Hasil Belajar, IPA.

\section{ABSTRACT}

The research was conducted to improve the process and learning outcomes by using concrete media on the Natural Sciences that available in Theme 7 sub-theme 1. The research was conducted on May 7-May 16, 2018 on the 4th grade of SD Negeri Tegalrejo 01 academic year 2017/2018. This type of research uses classroom action research. The data collection's techniques used teacher and student observations paper and multiple choice tests. The students' learning outcomes on pre-cycle, of 11 students with percentage 40,74\%, and 16 students did not pass with percentage 59,26\%. After making an improvements in cycle I, there were 19 students who pass the test with a percentage of 70,37\% and 8 students did not pass the test with a percentage of $29,63 \%$, the result from improvement of cycle I not reached yet that indicator that is $80 \%$ completeness, then implemented improvements cycle II. After the implementation of cycle II the completeness has been increasing, there were 23 students who pass the test with the percentage of $85.19 \%$ there were 4 students who did not pass with a percentage of $14.81 \%$. Thus improvement with Problem-Based Learning assisted with Concrete Media can be said successful because the learning achieves the goal of the percentage with 80\%.this result make Problem-Based Learning assisted with Concrete Media is recommended to make students more active in learning activities that take place.

Keyword: Problem Based Learning, Concrete Media, processes and Outcomes of learning,science 


\section{PENDAHULUAN}

Sekolah merupakan pondasi yang kokoh untuk membangun bangsa, namun berbagai permasalahan yang terjadi di sekolah terkadang menghambat peningkatan kualitas pendidikan (Airlanda, 2016: 43). Oleh karena itu pendidikan merupakan suatu aspek kehidupan yang begitu mendasar unuk pembangunan suatu negara.Menurut Sari \& Mawardi (2015: 82) sebagai seorang pendidik tidak hanya dituntut untuk memiliki pengetahuan dan keterampilan saat melakukan kegiatan belajar mengajar di kelas, tetapi juga harus memiliki kreativitas. Pembelajaran tematik yaitu pendekatan pembelajaran yang mengintegrasikan berbagai kompetensi dari berbagai mata pelajaran kedalam sebuah tema menggunakan empat pendekatan, yaitu intra disipliner, inter disipliner, multi disipliner, dan trans disipliner sehingga memberikan makna yang utuh kepada peserta didik (Prastowo, 2014: 10). Pembelajaran tematik integratif juga diartikan sebagai pembelajaran yang memadukan beberapa muatan pelajaran dalam satu kali tatap muka dan dikemas dalam sebuah tema sebagai pemersatu kegiatan pembelajaran (Mawardi 2014: 109). Maka, pembelajaran tematik akhirnya dirumuskan sebagai pembelajaran bermakna yang diikat oleh suatu tema dan terdiri dari beberapa mata pelajaran. Dalam pembelajaran tematik terdapat beberapa mata pelajaran dalam satu temanya yaitu Ilmu Pengetahuan Alam (IPA).Ilmu Pengetahuan Alam merupakan usaha manusia dalam memahami alam semesta melalui pengamatan yang tepat pada sasaran, serta menggunakan prosedur, dan dijelaskan dengan penalaran sehingga mendapatkan suatu kesimpulan (Susanto, 2013:167). Menurut Widiantono dan Harjono (2017: 200) bahwa pembelajaran IPA sebaiknya dilakukan secara sistematis, hal tersebut untuk menumbuhkan kemampuan peserta didik dalam berpikir kritis, bekerja, dan bersikap secara ilmiah.

Tujuan pembelajaran IPA SD/MI menurut Tursinawati (2013: 69) adalah sebagai berikut: 1) Memperoleh keyakinan terhadap kebesaran Tuhan Yang Maha Esa berdasarkan keberadapan, keindahan, dan keteraturan alam ciptaan-Nya, 2) Mengembangkan pengetahuan dan pemahaman konsep-konsep IPA ynag bermanfaat dan dapat diterapkan dalam kehidupan, 3) Mengembangkan rasa ingin tahu, sikap positif, dan kesadaran tentang adanya hubungan yang saling mempengaruhi antara IPA, lingkungan, teknolohi, dan masyarakat 4) Mengembangkan keterampilan proses untuk menyelidiki alam sekitar, memecahkan masalah, dan membuat keputusan, 5) Meningkatkan kesadarah untuk berperanserta dalam memelihara, menjaga, dan melestarikan lingkungan, 6) Meningkatkan kesadaran untuk menghargai alam dan segala keteraturannya sebagai salah satu ciptaan Tuhan, 6) Memperoleh bakal pengetahuan, konsep, dan keterampilan IPA sebagai dasar untuk melanjutkan pendidikan ke SMP/MTs.Pembelajaran di SD yang menggunakan tema dan subtema agar pemahaman siswa terhadap materi lebih mendalam dan berkesan sehingga siswa mampu mengenal bebagai konsep secara mudah dan jelas.

Menurut Dimyati dan Mudjiono, (2006:3) proses pembelajaran adalah suatu kegiatan intraksi antara guru dan siswa dimana akan diakhiri dengan proses evaluasi hasil belajar. Hamalik (2006: 162) berpendapat bahwa proses pembelajaran diartikan sebagai proses terjadinya interasi antara pelajar, pengajar dalam upaya mencapai tujuan pembelajaran yang berlangsung dalam suatu lokasi tertentu dalamjangka satuan waktu tertentu pula. Jadi dapat disimpulkan bahwa proses pembelajaran merupakan suatu proses 
interaksi antara guru dan siswa dimana akan diakhiri dengan proes evaluasi hasil belajar dalam upaya mencapai tujuan pembelajaran yang berlangsung dalam suatu lokasi dan jangka waktu tertentu. Proses pembelajaran dapat mempengaruhi hasil belajar siswa.

Menurut Jaeng (2007: 8) bahwa hasil belajar adalah suatu ukuran ketercapaian tujuan belajar yang dipengaruhi oleh faktor internal dan faktor eksternal. Hasil belajar dapat dijadikan suatu tolak ukur keberhasilan pembelajaran yang dilakukan. Menurut Abdurrahman (2009: 37) hasil belajar merupakan kemampuan yang diperoleh anak setelah melalui kegiatan belajar. Jadi dapat disimpulkan bahwa hasil belajar merupakan suatu ukuran ketercapaian tujuan belajar yang dijadikan sebagai tolak ukur kemampuan siswa setelah melalui kegiatan belajar.

Kenyataan di kelas 4 SD Negeri Tegalrejo 01 adalah guru mengikuti buku kurikulum 2013 tanpa didukung dengan media, yang mana membuat siswa jenuh. Bahkan ada juga siswa yang malah berbicara sendiri, sehingga membuat guru menegur siswa. Pembelajaran guru yang mengikuti buku paket tanpa didukung dengan media cenderung membuat siswa kurang aktif dan kurang menarik untuk siswa, siswa masih kurang paham dengan materi yang disampaikan oleh guru. Karena kurangnya penggunaan media sehingga membuat siswa tidak dapat aktif. Siswa hanya menyimak apa yang disampaikan oleh guru.Hal tersebur membuat fokus siswa terpecah. Sehingga pembelajaran menjadi membosankan dan hasil belajar siswa kurang dari KKM. Alternatif yang digunakan adalah dengan penggunaan model pembelajaran yang melibatan siswa untuk berperan aktif. Maka peneliti memilih salah satu model pembelajaran yang dapat diterapkan adalah dengan model Problem Based Learning berbantu media konkrit.
Problem Based Learning adalah pendekatan pembelajaran yang diawali dengan pemberian masalah kepada peserta didik dimana masalah tersebut dialami atau merupakan pengalaman sehari-hari peserta didik (Supinah dan Sutanti, 2010: 17).Model pembelajaran merupakan suatu kerangka konseptual untuk merancang dan melaksanakan suatu pembelajaran, mengorganisasikan pengalaman belajar untuk mencapai tujuan atau kompetensi, dan sebagai pedoman dalam proses pembelajaran karena berisi langkahlangkah pembelajaran yang sistematis. Model pembelajaran umumnya berkait erat dengan media pembelajaran. Media pembelajaran merupakan segala sesuatu yang dapat digunakan sebagai sarana untuk menyalurkan pesan dan informasi materi pembelajaran sehingga terjadi proses belajar (Mawardi, 2018: 29 ). Menurut Cahyo (2013: 283), pembelajaran berdasarkan masalah atau Problem Based Learning (PBL) adalah suatu model pembelajaran yang didasarkan pada prinsip menggunakan masalah sebagai titik awal akusisi dan integrasi pengetahuan baru. Sedangkan Sanjaya (2009: 214) juga berpendapat bahwa Problem Based Learning dapat diartikan sebagai rangkaian aktivitas pembelajaran yang menekankan pada proses penyelesaian masalah yang dihadapi secara ilmiah. Jadi model pembelajaran Problem Based Learning merupakan model pembelajaran yang didasarkan pada prinsip menggunakan masalah sebagai titik awal akuisisi dan intregrasi pengetahuan baru sebagai aktivitas pembelajaran yang menekankan pada proses penyelesaian masalah yang dihadapi secara ilmiah. Sehingga pada pembelajaran ini peserta didik yang selalu aktif, guru hanya sebagai fasilitator.

Prosedur pelaksanaan model Problem Based Learning menurut Hosnan (2013:325) adalah 1) mengorientasi peserta didik, 2) mengorganisasikan peserta didik 
untuk belajar, 3) membimbing penyelidikan individual/kelompok, 4) mengembangkan dan menyajikan hasil karya, 5) menganalisis dan mengevaluasi proses pemecahan masalah. Kelebihan Problem Based Learningmenurut Trianto (2010: 96) diantaranya adalah sesuai dengan kehidupan nyata peserta didik, konsep sesuasi dengan kebutuhan peserta didik, memupuk sifat inkuiri peserta didik, retensi konsep yang kuat, dan meningkatkan kemampuan memecahkan masalah. Kekurangannya ialah persiapan pembelajaran yang kompleks (persiapan masalah, alat, dan konsep), sulit mencari masalah yang relevan dengan siswa, sering terjadi miss konsepsi dan memakan banyak waktu.Pembelajaran menggunakan media benda konkrit atau nyata lebih mampu memberikan pengalaman riil kepada peserta didik karena peserta didik dapat melihat, merasakan dan meraba alat peraga yang digunakan guru. Pengalaman belajar yang lebih konkrit akan lebih tepat bagi anak usia sekolah dasar (Sumarjilah, 2015: 70).

Sebagai pendukung model Problem Based Learning peneliti memilih media konkrit. Menurut Nurkhotimah, Joharman, dan Suripto (2016: 256) model pembelajaran Problem Based Learning dengan media konkrit membuat siswa dapat memperoleh pengalaman nyata pada pembelajaran yang sedang berlangsung. Menurut Subhanarrijal, Triyono dan wahyudi (2016:285) model Problem Based Learning dengan media konkrit akan memberikan pengalaman langsung kepada siswa.

Melalui pelaksanaan penelitian ini diharapkan dapat memberikan manfaat. Hasil dari penelitian dengan model Problem Based Learning berbantu media konkrit dapat memancing rasa ingin tahu siswa sehingga dapat meningkatkan proses dan hasil belajar siswa. Dapat menjadi referensi guru dalam kegiatan pembelajaran.

\section{METODE PENELITIAN}

Jenis penelitian yang digunakan dalam penelitian ini merupakan penelitian tindakan kelas. Penelitian tindakan kelas merupakan suatu penelitian tindakan (Action Reseach) yang diharapkan dapat meningkatkan mutu dari suatu pembelajaran yang dilakukan sebagai bentuk upaya untuk memperbaiki tindakan pembelajaran (Arikunto, 2014:58).

Penelitian dilakukan menggunakan model pembelajaran Problem Based Learning $(P B L)$ dengan berbantu media konkrit di SD Negeri Tegalrejo 01 semester 2 tahun pelajaran 2017/2018 dari bulan februari hingga Mei 2018.

Subjek penelitian yang digunakan adalah siswa kelas 4 SD Negeri Tegalrejo 01 semester 2 tahun pelajaran 2017/2018 dengan jumlah 27 siswa terdiri dari 14 siswa laki-laki dan 13 siswa perempuan.

Teknik pengumpulan data yang digunakan berupa lembar aktivitas guru dan lembar aktivitas siswa, tes evaluasi, dan dokumentasi. Sedangkan pengujian validitas dilakukan di sekolah yang berbeda pada tingkatan yang sama. Jenis instrumen penelitian yang digunakan berupa tes evaluasi pilihan ganda dengan tingkat validitas $\leq 0,3$ dan ringkat reliabilitas soal pilihan ganda sebesar 0,885 pada soal siklus I dan 0,90 pada siklus II.

Teknik analisis data dengan menggunakan analisis deskriptif kuantitatif dan kualitatif. Data kuantitatif (angka) digunakan guna menunjukkan nilai kondisi awal, nilai setelah siklus I, nilai setelah siklus II, skor observasi guru dan siswa pada setiap siklusnya. Sedangkan Untuk observasi guru dan siswa pengolahan data analisis menggunakan teknik analisis deskriptif komparatif (data kualitatif) sehingga dapat dibandingkan dengan nilai hasil belajar muatan IPA setelah dilakukan siklus I dan siklus II.

Indikator kinerja dari penelitian yang dilakukan pada siswa kelas 4 melalui model pembelajaran Problem Based Learning 
berbantu media konkrit meliputi indikator proses dan indikator hasil.

\section{HASIL DAN PEMBAHASAN}

Penelitian yang dilakukan sesuai langkah-langkah model pembelajaran Problem Based Learning berbantu media konkrit dengan penelitian dilaksanakan dalam dua siklus, setiap siklus terdiri dari 3 pertemuan.

Hasil perbandingan proses pembelajaran guru dan siswa muatan IPA kelas 4 SD Negeri Tegalrejo 01 dari pra siklus, siklus I, dan siklus II mengalami peningkatan. Peningkatan proses

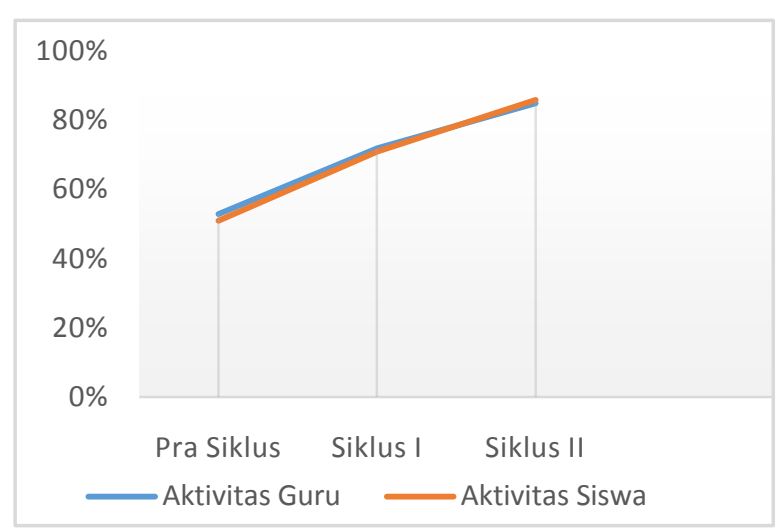

Gambar 1. Perbandingan Hasil Obervasi Aktifitas Guru dan Aktifitas Siswa Muatan IPA Pra Siklus, Siklus I, Dan Siklus II

Berdasarkan tabel 1 dapat disimpulkan bahwa dengan penggunaan model pembelajaran Problem Based Learning berbantu media konkrit dapat

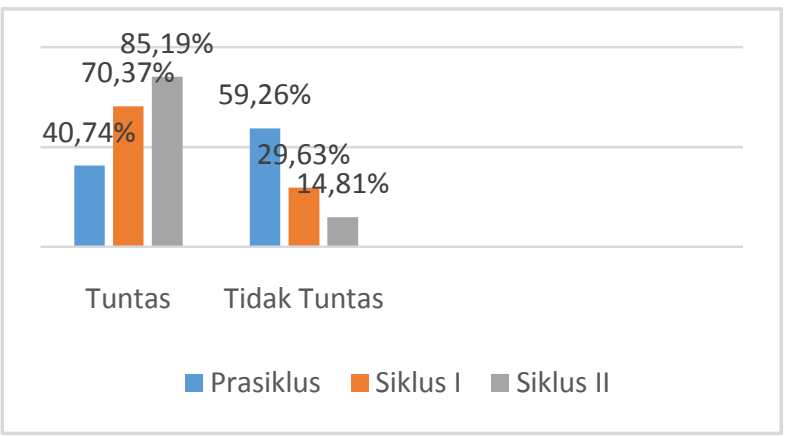

Gambar 2. Perbandingan Nilai Hasil Belajar Muatan IPA Pra Siklus, Siklus I, Dan Siklus II.

Dari tabel 2 dapat di simpulkan bahwa setelah melakukan perbaikan pembelajaran dapat dilihat pada gambar 1 berikut.

meningkatkan proses pembelajaran Aktivitas guru dan aktivitas siswa. Persentase hasil observasi guru mengalami peningkatan dari pra siklus dengan persentase $53 \%$ meningkat menjadi $72,5 \%$ pada siklus I. Pada siklus II meningkat menjadi $85,5 \%$. Sama halnya dengan aktivitas siswa mengalami peningkatan pada setiap siklusnya. Aktivitas siswa mengalami peningkatan dari pra siklus dengan persentase $51,67 \%$ meningkat di siklus I persentase $71,66 \%$. Dan pada siklus II mengalami peningkatan mencapai $86,5 \%$.

Peningkatan proses pembelajaran mempengaruhi hasil belajar siswa SD Negeri Tegalrejo 01 yang diperoleh siswa. peningkatan hasil belajar siswa dapat dilihat pada gambar 2 berikut.

pembelajaran dengan Model Problem Based Learningberbantumedia konkrit hasil belajar siswa kelas 4 SD Negeri Tegalrejo 01 mengalami peningkatan pada setiap siklus. Pada pra siklus siswa yang tuntas berjumlah 11siswa dengan persentase $40,74 \%$, sedangkan siswayang tidak tuntas berjumlah 16 dengan persentase 59,26\%. Setelah melakukan perbaikan pada siklus I terjadi peningkatan yaitu siswa yang tuntas berjumlah 19 orang dengan persentase $70,37 \%$ dan siswa yang tidak tuntas berjumlah 8 orang dengan persentase $29,63 \%$, hasil dari perbaikan siklus I belum mencapai indikator pencapaian yakni $80 \%$ ketuntasan, oleh sebab itu di laksanakan 
perbaikan siklus II. Setelah pelaksanaan siklus II terjadi peningkatan yaitu siswa yang tuntas berjumlah 23 dengan persentase $85,19 \%$ sedangakan siswa yang tidak tuntas berjumlah 4 orang dengan persentase $14,81 \%$. Dengan demikian perbaikan pembelajaran dengan Model Problem Based Learning Berbantuan Media konkrit dapat di katakan berhasil karena hasil belar mencapai tujaun yakni persentase $80 \%$.

\section{Pembahasan}

Berdasarkan penelitian yang dilakukan di kelas 4 SD Negeri Tegalrejo 01 tema 7 sub tema 1 mengalami peningkatan proses dan hasil belajar dengan model Problem Based Learning berbantu media konkrit dari pra siklus hingga siklus II. Persentase hasil observasi guru mengalami peningkatan dari pra siklus dengan persentase $54,54 \%$ meningkat menjadi $70 \%$ pada siklus I pertemuan I dan $75 \%$ pada pertemuan kedua. Pada siklus II pertemuan I meningkat $83 \%$ dan menjadi $88 \%$ dipertemuan II dengan kriteria baik. Sama halnya dengan aktivitas siswa mengalami peningkatan pada setiap siklusnya.aktivitas siswa mengalami peningkatan dari pra siklus dengan persentase $56,81 \%$ meningkat di siklus I pertemuan I dan pertemuan II dengan persentase $71,66 \%$. Dan pada siklus II mengalami peningkatan mencapai $83 \%$ pertemuan I dan meningkat lagi pada pertemuan II mencapai $90 \%$ dengan kriteria sangat baik.

Meningkatnya proses pembelajaran berpengaruh terhadap hasil belajar yang diperoleh siswa kelas 4 SD Negeri Tegalrejo 01. Pada pra siklus hasil belajar siswa yang tuntas berjumlah 11siswa dengan persentase $40,74 \%$, sedangkan siswayang tidak tuntas berjumlah 16 dengan persentase 59,26\%. Setelah melakukan perbaikan pada siklus I terjadi peningkatan yaitu siswa yang tuntas berjumlah 19 orang dengan persentase $70,37 \%$ dan siswa yang tidak tuntas berjumlah 8 orang dengan persentase $29,63 \%$. Karena hasil dari perbaikan siklus I belum mencapai indikator pencapaian yakni $80 \%$ ketuntasan, oleh sebab itu di laksanakan perbaikan siklus II. Setelah pelaksanaan siklus II terjadi peningkatan yaitu siswa yang tuntas berjumlah 23 dengan persentase $85,19 \%$ sedangakan siswa yang tidak tuntas berjumlah 4 orang dengan persentase $14,81 \%$. Dengan demikian perbaikan pembelajaran dengan Model Problem Based Learning Berbantuan Media konkrit dapat di katakan berhasil karena hasil belar mencapai tujaun yakni persentase $80 \%$.

Penelitian relevan yang dilakukan oleh Ariesta Kusuma Wardani (2016) menunjukan bahwa proses dan hasil belajar siswa mengalami peningkatan dengan model Problem Based Learning berbantu media gambarpada pembelajaran IPA kelas 4. Walaupun berbeda media yang digunakan namun model pembelajaran Problem Based Learning dapat meningkatkan proses dan hasil belajar siswa.

Penelitian yang dilakukan oleh Mustalimah (2015) pada jurnal Scholaria, tahun 2015 dengan judul "Peningkatan Keterampilan Proses dan Hasil Belajar menggunakan model Problem Based Learning pada Tema Merawat Tubuhku Siswa Kelas I SD Negeri I Gosono Wonosegoro" meskipun diterapkan pada mata pelajaran yang berbeda, model Problem Based Learning dapat meningkatkan proses dan hasil belajar siswa.

\section{PENUTUP \\ Simpulan}

Berdasarkan hasil penelitian dan pembahasan yang telah dipaparkan dapat disimpulkan bahwa penggunaan model pembelajaran Problem Based Learning berbantuan media konkrit berhasil meningkatkan proses dan hasil belajar Tema 7 subtema 1 muatan IPA pada siswa kelas 4 SD Negeri Tegalrejo 01. Hal tersebut dapat terlihat dari peningkatan hasil observasi proses pembelajaran yang dilakukan meliputi observasi aktivitas guru dan siswa serta hasil belajar muatan IPA 
yang diperoleh.Persentase hasil observasi guru mengalami peningkatan dari pra siklus dengan persentase $54,54 \%$ meningkat menjadi $70 \%$ pada siklus I pertemuan I dan 75\% pada pertemuan kedua. Pada siklus II pertemuan I meningkat $83 \%$ dan menjadi $88 \%$ dipertemuan II dengan kriteria baik. Sama halnya dengan aktivitas siswa mengalami peningkatan pada setiap siklusnya.aktivitas siswa mengalami peningkatan dari pra siklus dengan persentase $56,81 \%$ meningkat di siklus I pertemuan I dan pertemuan II dengan persentase $71,66 \%$. Dan pada siklus II mengalami peningkatan mencapai $83 \%$ pertemuan I dan meningkat lagi pada pertemuan II mencapai $90 \%$ dengan kriteria sangat baik.

Seiring dengan peningkatan proses pembelajaran, maka berpengaruh pada hasil belajar muatan IPA juga mengalami peningkatan. Hal ini ditunjukkan dengan perbandingan hasil belajar muatan IPA berdasarkan ketuntasan belajar dengan $\mathrm{KKM} \geq 70$. Hasil analisis diketahui bahwa siswa yang tuntas sebelum tindakan adalah 11 siswa dengan persentase $40,74 \%$. Setelah diberikan tindakan pada siklus I terjadi peningkatan jumlah ketuntasan siswa menjadi 19 siswa dengan persentase $70,37 \%$. Setelah diberikan tindakan pada siklus II, terjadi lagi peningkatan jumlah ketuntasan menjadi 23 siswa dengan persentase $85,19 \% \%$. Siswa yang belum tuntas sebelum diberikan tindakan adalah 16 siswa dengan persentase $59,74 \%$. Setelah diberikan tindakan pada siklus I, berkurang menjadi 8 siswa dengan persentase $29,63 \%$. Setelah dilaksanakan lagi tindakan pada siklus II menjadi 4 siswa dengan persentase $14,81 \%$ yang belum tuntas. Dengan demikian dapat disimpulkan bahwa penerapan model Problem Based Learning berbantu media konkrit dapat meningkatkan proses dan hasil belajar siswa kelas 4 SD Negeri Tegalrejo 01 pada tahun ajaran 2017/2018.

\section{DAFTAR RUJUKAN}

Airlanda, G. S. 2016. Analisis Kualitas Pendidikan Ditinjau dari Penerapan Kebijakan Sekolah Gratis di SMA Negeri 1 Weru Kabupaten Sukoharjo. Jurnal Pendidikan Sains. 4(1): 43.

\section{Eggen, P., dan Kauchak, D. 2015. Strategi} dan Model Pembelajaran Mengajar Konten dan Keterampilan Berpikir. Jakarta: Indeks.

Hosnan, M. 2014. Pendekatan saintifik dan kontekstual dalam pembelajaran abad 21: Kunci sukses implementasi kurikulum 2013. Ghalia Indonesia

Mawardi, M. 2014. Pemberlakuan Kurikulum SD/MI Tahun 2013 dan Implikasinya Terhadap Upaya Memperbaiki Proses Pembelajaran Melalui PTK. Scholaria: Jurnal Pendidikan dan Kebudayaan, 4(3): 109.

Mawardi. 2018. Merancang Model dan Media Pembelajaran. Scholaria.1(1): 29.

Nurkhotimah, S. Joharman. Suripto. 2016. Penerapan model Problem Based Learning (PBL) dengan Media Konkrit Untuk Meningkatkan Hasil Belajar Matematika Tentang Operasi Hitung Pecahan Pada Siswa Kelas V SDN 1 Kuwayuhan Tahun Ajaran 2016/2017. Kalam Cendekia. 5(3): 256

Prastowo, A. 2014. Pemenuhan Kebutuhan Psikologis Peserta Didik SD/MI Melalui Pembelajaran TematikTerpadu. Jurnal Pendidikan Sekolah Dasar. 1(1): 10.

Sari, D. L., Mawardi. 2015. Keefektifan Model Pembelajaran Picture And Picture dan Make a Match Ditinjau dari Hasil Belajar Dalam Pembelajaran IPA Kelas 4 SD Gugus Mawar-Suruh. Scholaria. 5(3): 87.

Sanjaya, Wina. 2009. Strategi Pembelajaran Berorientasi Standar 
Proses Pendidikan. Jakarta: Kencana Prenada Media Group

Subhanarrijal, A. Triyono. Wahyudi. 2016. Penerapan Model Problem Based Learning dengan Media Konkret dalam Pembelajaran Pecahan Pada Siswa Kelas IV SDN 01 Bojongsari Tahun Ajaran 2015/2016. Kalam Cendekia. 4(3): 285

Supinah, dan Sutanti, Titik. 2010. Pembelajaran Matematika di SD. Yogyakarta: PPPPTK Matematika.

Sumarjilah, Y. 2015. Penggunaan Media Kongkrit untuk Meningkatkan Hasil Belajara Matematika Pokok Bahasan Penjumlahan dan Pengurangan Bilangan pada Siswa Kelas 1 SDN Rejoagung 01 Kebupaten Jember. Pancaran. 4(4): 70.

Trianto, M. P. 2010. Model Pembelajaran Terpadu. Jakarta: Bumi Aksara

Tursinawati. 2013. Analisis Kemunculan Sikap Ilmiah Siswa dalam Pelaksanaan Percobaan pada Pembelajaran IPA di SDN Kota Banda Aceh. Jurnal Pionir. 1(1): 69.

Widiantono, N., dan Harjono, N. 2017. Penerapan Model Pembelajaran Interaktif untuk Meningkatkan Aktivitas dan Hasil Belajar IPA Siswa Kelas 5 SD. Scholaria. 7(3): 200. 